\title{
Impact of Financial Crisis on Firms' Capital Structure in UK, France, and Germany
}

\author{
Abdullah Iqbal \\ University of Kent, $U K$ \\ Ortenca Kume* \\ University of Kent, $U K$
}

This study examines the impact of the recent financial crisis on the capital structure decision of UK, French and German firms. The results show that overall leverage ratios increase from pre-crisis (2006 and 2007) to crisis (2008 and 2009) years and then decrease in the post-crisis (2010 and 2011) years. Both equity and debt levels change during the crisis and post-crisis years. The findings further reveal that firms with lower than industry average capital structure ratios in the pre-crisis period experience a gradual increase in their leverage during crisis and post-crisis periods. However, firms with higher than industry average capital structure ratios in the pre-crisis periods experience a significant decrease in the leverage ratios particularly in the post-crisis period mainly due to changes in their equity levels. (JEL: G14, G15, G32)

Keywords: financial crisis; capital structure; leverage; UK; France; Germany

\section{Introduction}

Most of the extant literature shows that changes in capital structure affect firm value. Prior studies (Demirgüç-Kunt and Maksimovic, 1999; Booth et al., 2001; Graham, Leary and Roberts, 2014, etc.) find that the capital structure decision is influenced not only by firm-specific factors but also by institutional settings and macroeconomic uncertainty. This study examines changes in capital structures of non-financial/non-utility European firms around the crisis period of 2007-08. It focuses mainly

\footnotetext{
* Dr Ortenca Kume, Lecturer in Finance, Kent Business School, University of Kent, Canterbury, CT2 7PE, UK. Email: O.Kume@kent.ac.uk
}

(Multinational Finance Journal, 2014, vol. 18, no. 3/4, pp. 249-280)

(C) Multinational Finance Society, a nonprofit corporation. All rights reserved. DOI: $10.17578 / 18-3 / 4-3$ 
on the UK, France, and Germany because these countries represent the most developed countries in Europe. Further, these countries have different financial and institutional characteristics with UK being a market-based economy (similar to the US) and France and Germany on the other side being typical bank-based economies (similar to Japan). There are differences even among firms operating in bank-based economies. For example, Brun et al. (2013) argue that German firms employ higher levels of debt than their UK and French counterparts due to their long-term relationship with "HausBanks". Bancel and Mittoo (2011) note that French economy was hit harder than UK and German economies during the crisis. They also show that unlike their German counterparts, French firms relied heavily on trade financing. However, none of these papers examines the time-series variation in leverage levels across firms in all three countries (the UK, France, and Germany) around the recent financial crisis.

The major contribution of this study is that it provides an insight on the impact of 2007-08 financial crisis on capital structure decisions of non-financial/non-utility firms in market-based (UK) and bank-based (France and Germany) economies. Secondly, it identifies the financing alternatives (short-term debt, long-term debt or equity) that are used by firms operating in these economies around the crisis period. Finally, it shows how leverage ratios change during and after the crisis period for firms with conservative and aggressive pre-crisis leverage ratios.

The results indicate that, on average, leverage ratios for firms in the UK and Germany increase from pre-crisis (2006-2007) to crisis period (2008-2009) but decrease from crisis (2008-2009) to post-crisis (2010-2011) period. However, leverage ratios from pre-crisis level to post-crisis level are not significantly different from each other suggesting that post-crisis leverage ratios of these firms are back to similar levels as they were in the pre-crisis period with an adjustment in the interim (i.e. crisis period). This study finds no evidence of a significant change in the leverage ratios from pre- to crisis and from crisis to post-crisis period for French firms. In addition, leverage ratios of firms with pre-crisis conservative capital structure across the three countries increase significantly during the crisis period due to higher debt levels. Contrarily, leverage ratios of firms with pre-crisis aggressive capital structure decrease from pre- to post-crisis period. While the gradual decrease in leverage ratio from pre- to post-crisis period for the UK firms is due to significant and gradual changes in both debt and equity, the significant change in the leverage ratio for 
German and French firms occurs in the post-crisis period and is mainly due to the increase in the levels of equity. The panel data regression results also confirm that crisis period has had a significant impact on the leverage ratios of both aggressive and conservative subsamples. Overall, these observations are consistent with those of Graham and Harvey (2001), Leary and Roberts (2005), Fosberg (2012), and Graham, Leary and Roberts (2014). Finally, the results show that changes in capital structure can be attributed to an active use of both short-term and long-term debt as well as equity, during and after the crisis period.

The rest of the study is organised as follows. Section II reviews the existing literature on leverage changes in different countries during different crisis periods. Section III describes data selection and research methodology. Section IV presents empirical findings. Finally, Section $\mathrm{V}$ summarises and concludes the paper.

\section{Literature review}

The financial crisis that started at the end of 2007 in the subprime credit market led to a liquidity crisis in the short-term money markets (Brunnermeier, 2008; Fosberg 2012, etc). The crisis had its consequences in many European countries where troubled mortgage providers or banks were rescued (Hodson and Quaglia, 2009; Alter and Schóler, 2012). Consequently banks were asked to issue additional equity to maintain the minimum required capital ratios. Lack of banks' confidence on each other's financial securities led to an increase in the interbank lending rates and consequently to a reduction in the supply of loans to non-financial firms (Fosberg 2012).

Kahle and Stulz (2013) argue that the financial crisis of 2007-08 created a supply shock even in the equity markets due to the flight to quality in bond markets, which made it costly for high-levered firms to raise additional equity. In addition, this crisis resulted in a lower demand for consumption and higher uncertainty about economic recovery thus leading to a decline in demand for products and services and resultantly a fall in debt and equity issuance and an increase in cash holdings due to postponement of investments. Graham, Leary, and Roberts (2014) report that during periods of economic downturns (or uncertainty), investment opportunities are rare and hence the need for external capital is weak leading to a reduction in firms' leverage ratios. Based on a survey of U.S. chief financial officers' views about the 
impact of 2007-08 crisis on firms' financial performance, Campello, Graham, and Harvey (2010) find that due to the reduction in demand as well as cash flows, additional funding was perceived costly and difficult to raise thus there was no additional demand for funding.

Overall, empirical evidence on the impact of various financial crises on firms' capital structure is sparse. Lim (2003) finds that large Korean firms left financial intermediaries and turned to capital markets after the Korean crisis. Similarly, Voutsinas and Werner (2011) note that extreme credit supply fluctuations in Japan had a significant negative impact on Japanese firms' financial leverage levels. This impact was more pronounced for bank-dependent firms. Consistent with the previous studies, Balsari and Kirkulak (2010) report a negative impact of 1994 crisis on Turkish firms' leverage ratios, but note that the rise in short-term debt and the fall in Turkish firms' equity levels during the 2001-02 financial crisis led to a positive impact of this crisis on firms' leverage ratios.

Empirical studies considering the impact of 2007-08 financial crisis on capital markets (Fosberg, 2012 and Kahle and Stulz, 2013) reveal that, in general, firms relied heavily on the use of public debt markets during the crisis. Kahle and Stulz (2013) note that net debt issuances increased during the first year of the 2007-08 crisis for both bank-dependent and non-bank-dependent firms, but fell after 2008. Fosberg (2012) also report significant increase in debt ratios of US firms over the pre-crisis period of 2006-08 followed by a gradual decline in debt levels by the end of 2010 (i.e. post-crisis period) to the pre-crisis level. Pattani, Vera, and Wackett (2011) observe similar patterns in public debt issued by UK firms. They also report an increase in public equity issuance in 2008-09 and a decline in 2009-10. They further note that the increase in equity issuance (not a first time issue) was mainly used for bank loan repayments because managers perceived their firms to have high pre-crisis leverage ratios. On the contrary, the proceeds from equity issuance in 2010-11 were used to finance new projects. Akbar, Rehman, and Ormrod (2013) find that the crisis did not have a significant impact on the long-term financing channels for UK private firms, but impaired the financing channels of short-term debt and trade-credit for these firms. They also suggest that in order to hedge against the negative impact of credit contractions, UK private firms held more cash and issued more equity. Similarly, Brun et al. (2013) argue that the increase in equity of French firms after the crisis resulted mainly from the increase in retained earnings particularly for SMEs and 
an increase in the issue premiums received by large firms.

Overall, prior literature offers mixed results on changes in capital structure during various crises periods in different countries/institutional settings. This study aims to shed further light on changes in leverage ratios of European firms during and after 2007-08 financial crisis.

\section{Data and methodology}

The sample in the study consists of firms from three major European countries that are UK, France, and Germany over 2006-11 period. The relevant data are extracted from Datastream. Initial sample is selected using the following criteria:

1. Firms are listed on London Stock Exchange for UK, Euronext Paris for France, and Frankfurt Stock Exchange for Germany.

2. Firms operate in non-financial and non-utility sectors.

These criteria produce initial samples of 1748 firms for UK, 1622 for France, and 1345 for Germany. Outliers and firms with negative market values and negative capital structure ratios are also excluded. Both for France and Germany, some firms appear twice or more with similar figures in the shortlisted sample. Upon investigation, it is found that Datastream uses separate codes for the same firm if it has issued further equity, thus such French and German firms are also removed. Firms that do not belong to any Datastream Level-3 Industry Group are also excluded. Finally, firms for which Datastream does not provide enough data to estimate the leverage ratio ((short-term debt + long-term debt)/total capital) during either the 'pre-crisis and crisis' years or 'crisis and post-crisis' years are removed too.

These restrictions produce samples of 871 firms for UK, 564 for France, and 392 for Germany across 13 Level-3 Datastream industry sectors, as reported in table 1 . The study uses firm-year observations for analysis, which vary depending on the availability of relevant data.

Capital structure or leverage ratio (LEV) is estimated for each year across all firms for each industry group. Similar to Al-Najjar and Hussainey (2011), capital structure ratio is measured as total debt to total capital ratio, where total debt is estimated as the sum of total (longand short-term) loans and preference capital, and total capital includes 
TABLE 1. Distribution of sample firms by industry (Datastream Level-3) for each country

\begin{tabular}{lccc}
\hline Sector & UK & France & Germany \\
\hline Automobiles \& Parts & - & 15 & 17 \\
Basic Resources & 57 & 14 & 9 \\
Chemicals & 15 & 15 & 22 \\
Construction and Materials & 35 & 22 & 15 \\
Food and Beverage & 35 & 42 & 17 \\
Healthcare & 72 & 45 & 28 \\
Ind. Goods \& Services & 268 & 116 & 99 \\
Media & 76 & 48 & 23 \\
Oil \& Gas & 61 & 13 & 25 \\
Personal \& Household Goods & 43 & 59 & 39 \\
Retail & 50 & 30 & 20 \\
Technology & 94 & 119 & 67 \\
Travel and Leisure & 65 & 26 & 11 \\
\hline Overall (Total) & 871 & 564 & 392 \\
\hline
\end{tabular}

Note: The table reports the distribution of sample firms by country and industry using Datastream Level-3 industrial classification, for the three countries.

both total debt and total shareholders' equity. ${ }^{1}$ This measure of leverage ratio is also consistent with previous studies undertaken in this area (Harris and Raviv, 1991; Rajan and Zingales, 1995; Chen, 2004; Leary and Roberts, 2005; Huang and Song, 2006).

Financial years 2006 and 2007 are defined as 'pre-crisis' period, 2008 and 2009 as 'crisis' period, and 2010 and 2011 as 'post-crisis' period. The study employs t-tests for difference in means (assuming unequal variances) to identify if equally-weighted mean leverage ratios are significantly different from each other during the three periods namely 'pre-crisis to crisis', 'crisis to post-crisis', and 'pre-crisis to post-crisis'. Prior literature suggests that firms have target leverage ratios (Leary and Roberts, 2005) and they use debt and/or equity to adjust their interim capital structure. This study uses t-test to examine whether there are any significant changes in the levels of debt (shortand/or long-term) or equity across the three periods.

This study further investigates the changes in leverage ratios of sample firms by classifying them into two subsamples based on whether their pre-crisis leverage ratios are higher or lower than their

1. We use alternative measures of leverage ratio and find similar results. 
Level-3Datastream industry mean leverage ratios. ${ }^{2}$ Datastream industry mean leverage ratios. Firms with higher than industry mean leverage ratios are identified as aggressive and those with lower than industry mean values are named as conservative subsamples. Again, t-test is used to examine differences in mean leverage ratios and debt and equity levels between pre-crisis, crisis and post-crisis periods for each of these two subsamples across the three countries.

This paper also examines the impact of the financial crisis on firms' leverage ratios in a more formal setting. Similar to Lemmon, Roberts, and Zender (2008), a fixed-effect panel data regression model is used, including crisis and post-crisis dummies, to capture the impact of the financial crisis. The model also controls for other firm-specific factors that may have an impact on leverage ratios, as suggested by Frank and Goyal (2003):

$$
\begin{aligned}
L E V_{i t}= & \beta_{0}+\beta_{1} \text { Tangibility }_{i t}+\beta_{2} \text { Size }_{i t}+\beta_{3} M V B V_{i t}+\beta_{4} \text { Growth }_{i t}+ \\
& \beta_{5} \text { AssetUniqueness }_{i t}+\beta_{6} \text { BusinessRisk }_{i t}+\beta_{7} \text { PPETA }_{i t}+ \\
& \beta_{8} \text { ROA }_{i t}+\beta_{9} C D+\beta_{10} \text { POCD }+u_{i}+e_{i t}
\end{aligned}
$$

where: asset tangibility (Tangibility) ratio is calculated as fixed assets divided by total assets while fixed assets are estimated as the difference between total and short-term assets; firm's size (Size) is defined as the natural logarithm of firm's total assets; the market value to book value ratio $(M V B V)$ is employed to capture firm's growth opportunities; growth (Growth) is a proxy for firm's growth in total assets and measured as the change in total assets; firm's uniqueness (AssetUniqueness) proxy is defined as research and development expenses divided by total assets; business risk variable (BusinessRisk) is defined as the coefficient of variation in sales over five-years on rolling basis (standard deviation of sales/average of sales); PPETA represents the ratio of property, plant and equipment divided by total assets; return on assets (ROA) is estimated as net income before preferred dividends divided by total assets; crisis period $(C D)$, the main variable of interest, in the regression model is represented by a dummy variable that takes a value of 1 for years 2008 and 2009 and zero for 2006-2007 (pre-crisis period) and 2010-2011 (post-crisis period); post-crisis period dummy $(P O C D)$ variable takes the value of 1 for years

2. Please refer to table 1, for Level-3 Datastream industry classifications. 
2010 and 2011 and zero for the other years in the sample period.

To account and control for time-varying changes in firms' observable determinants of leverage, crisis and post-crisis dummies are interacted with control variables in Equation 1, as follows: ${ }^{3}$

$$
\begin{aligned}
& L E V_{i t}=\beta_{0}+\beta_{1} \text { Tangibility }_{i t}+\beta_{2} \text { Size }_{i t}+\beta_{3} M V B V_{i t}+\beta_{4} \text { Growth }_{i t}+ \\
& \beta_{5} \text { AssetUniqueness }_{i t}+\beta_{6} \text { BusinessRisk }_{i t}+\beta_{7} \text { PPETA }_{i t}+ \\
& \beta_{8} R O A_{i t}+\beta_{9} C D+\beta_{10} P O C D+\beta_{11} \text { Tangibility } * C D_{i t}+ \\
& \beta_{12} \text { Size } * C D_{i t}+\beta_{13} M V B V * C D_{i t}+\beta_{14} \text { Growth } * C D_{i t}+ \\
& \beta_{15} \text { AssetUniqueness } * C D_{i t}+\beta_{16} \text { BusinessRisk } * C D_{i t}+ \\
& \beta_{17} \text { PPETA } * C D_{i t}+\beta_{18} R O A * C D_{i t}+ \\
& \beta_{19} \text { Tangibility } * P O C D_{i t}+\beta_{20} \text { Size } * P O C D_{i t}+ \\
& \beta_{21} M V B V * P O C D_{i t}+\beta_{22} \text { Growth } * P O C D_{i t}+ \\
& \beta_{23} \text { AssetUniqueness } * P O C D_{i t}+ \\
& \beta_{24} \text { BusinessRisk } * P O C D_{i t}+\beta_{25} \text { PPETA } * P O C D_{i t}+ \\
& \beta_{26} R O A * P O C D_{i t}+u_{i}+e_{i t}
\end{aligned}
$$

\section{Empirical findings}

\section{A. Univariate results}

Table 2 reports descriptive statistics of all variables across all firm-year observations used in this study. Similar to Dang (2013), the figures show that the mean leverage ratio $(26.40 \%)$ in the UK (a market-based economy) is lower than the respective mean ratios $(32.40 \%$ and $33.10 \%$ ) in France and Germany (bank-based economies). Median values of leverage ratios also depict a similar picture. It is also clear that the average level of debt as a percentage of equity is the lowest (about $48 \%$ of equity) in the UK and highest (about $111 \%$ of equity) in Germany with France in the middle (about $83 \%$ of equity).

Figure 1 graphically presents annual mean leverage ratios for the full sample of firms for each country from 2006 to 2011. It shows that the

3. We thank the anonymous referee for this suggestion. 


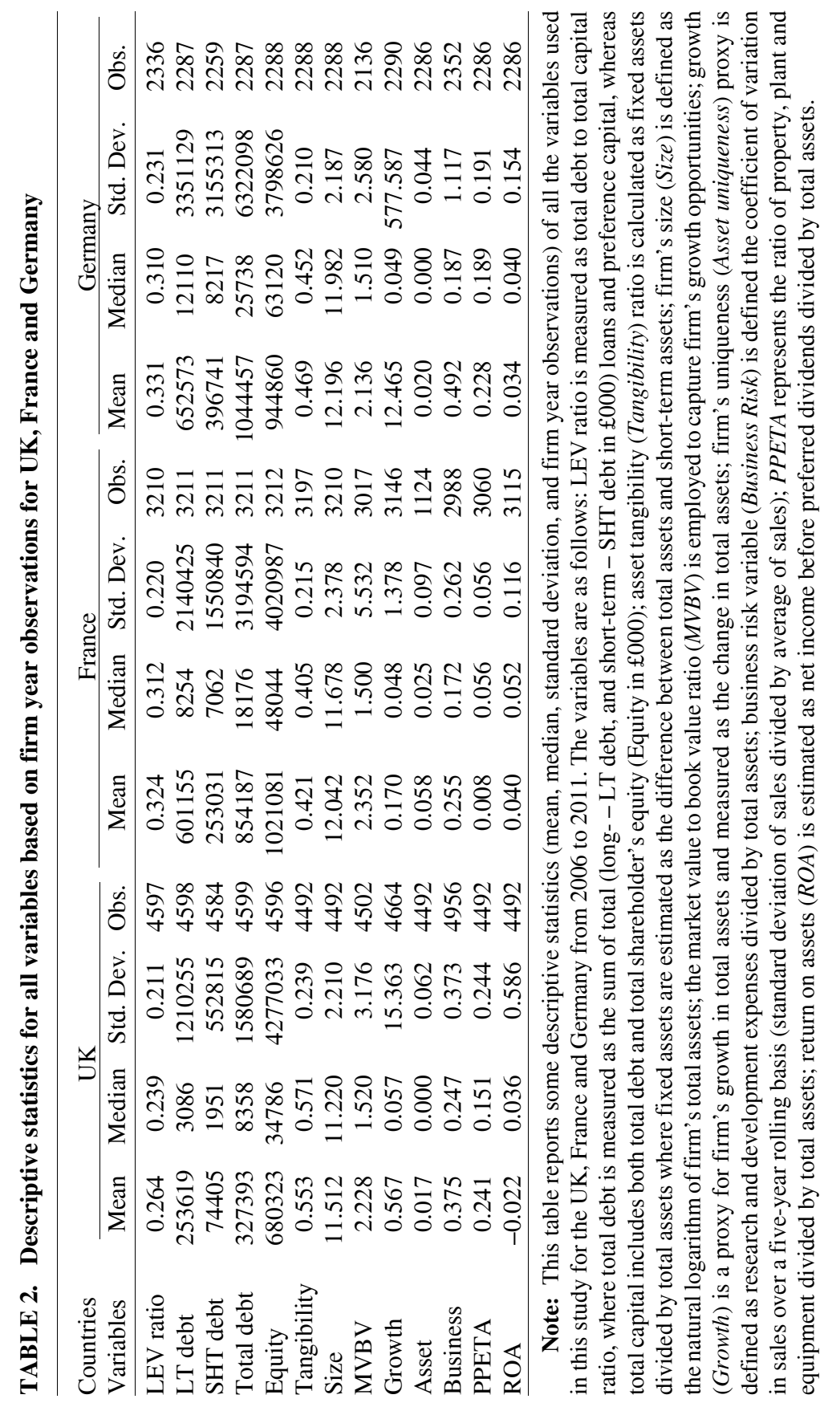




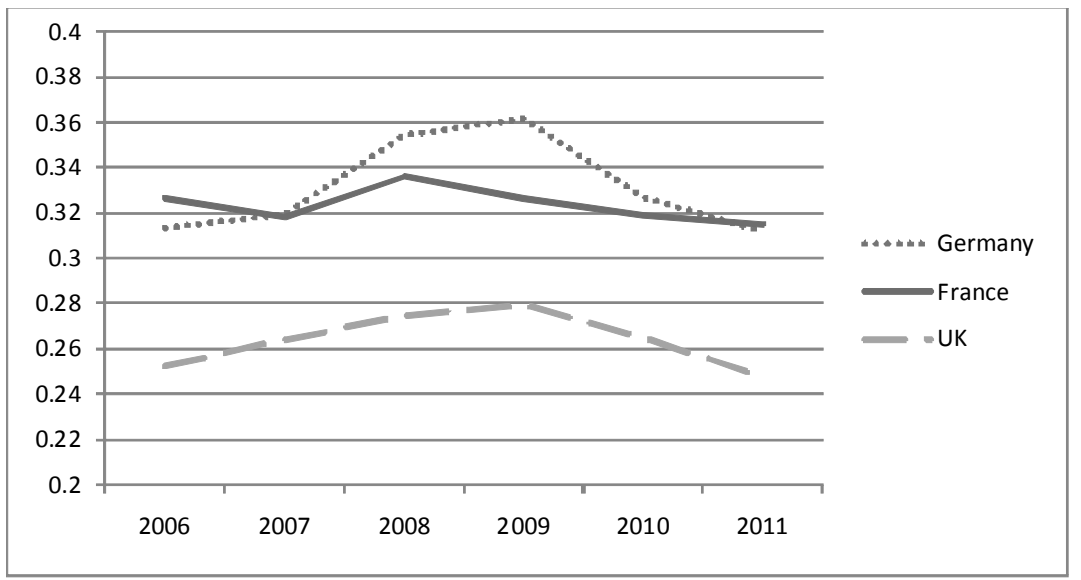

FIGURE 1.- Graph of annual mean leverage ratios for the full sample for UK, France and Germany

Note: This graph shows annual mean leverage ratios for the UK, French and German sample firms. Leverage ratio is determined as total debt to total capital ratio, where total debt is measured as the sum of total (long- and short-term debt) loans and preference capital, while total capital includes both total debt and total shareholder's equity of sample firms over the period 2006-2011.

mean leverage ratio is higher for German firms than for French and UK firms across all years except in 2006. It also shows that leverage ratios increase for German and UK firms from pre-crisis (2006 and 2007) to crisis years (2008 and 2009) and decline in the post-crisis years (2010 and 2011). The trend in leverage ratios for both UK and German firms looks similar during the sample period despite differences in their institutional settings. On the other hand, mean leverage ratio for French firms does not show such a pattern. It decreases steadily from 2008 onwards. Overall, by 2011, the mean leverage ratios for UK and German firms are back to their 2006 levels, whereas for French firms the mean leverage ratio in 2011 is slightly lower than the level in 2006.

Table 3 reports mean and t-test results for leverage ratios and its components (short-term debt, long-term debt, and equity) across three periods: pre-crisis (2006-2007), crisis (2008-2009) and post-crisis (2010-2011) for the full sample (Panel A), conservative sub-sample (Panel B) and aggressive sub-sample (Panel C). For UK, Panel A figures indicate that mean leverage ratio of $27.70 \%$ for the crisis period is 
higher than the level in pre-crisis $(25.80 \%)$ and post-crisis $(25.70 \%)$ periods. This trend shows an increase in leverage ratios during the crisis period and a decrease after the crisis with both of these changes being statistically significant at the $1 \%$ level. Additionally, t-test results show that there is no significant difference in leverage ratios between the preand post-crisis periods.

The trend in leverage ratios for German firms is also similar to that of UK with an initial increase during the crisis period and then a reversal after the crisis years. These results are in line with those reported by Leary and Roberts (2005) for the US market. Finally, leverage ratios in French firms show a steady downward trend in crisis and post-crisis years with none of the changes being statistically significant. Overall, univariate results indicate that leverage ratios of sample firms in all three countries change during the crisis and/or in the post-crisis periods.

Panel A also shows whether it is equity or debt that causes the change in capital structures of sample firms during and/or after the crisis. The changes in equity are significant in UK firms during the crisis years however this is not the case for French or German firms. ${ }^{4}$ The t-test results show a significant increase in equity levels for sample firms in UK and France in the post-crisis years when compared to their pre-crisis or the crisis years' levels. For German firms, the change in equity is only significant from pre- to post-crisis period. Panel A shows that mean levels for total debt also increase significantly from pre-crisis to both crisis and post-crisis periods for UK firms, but this increase is significant only from pre-crisis to the post-crisis period for French firms. However, German firms do not experience any significant change in their total debt levels either in the crisis or post-crisis years. This shows that in Germany (a bank-based economy), debt levels did not change however equity levels increase overall from pre- to post-crisis years.

Akbar, Rehman, and Ormrod (2013) find that during the financial crisis of 2007-08, changes in short-term debt led to changes in capital structures of UK private firms. This paper also examines if it is the long-term or the short-term debt that leads to a change in the capital structure in the short-run. The results are mixed. For example, Panel A

4. This is consistent with the statistics reported by London Stock Exchange for further equity issues in the UK. 


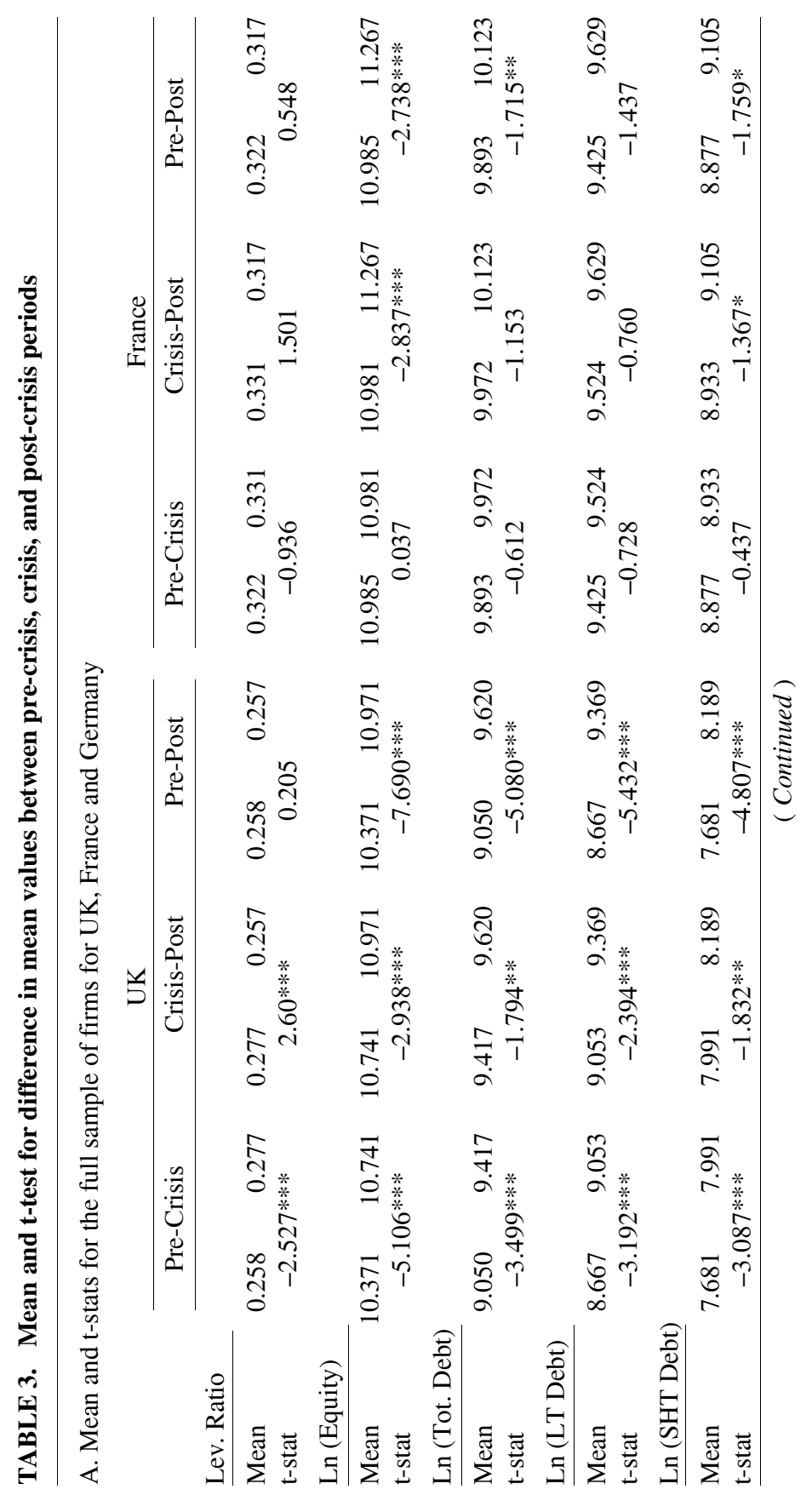




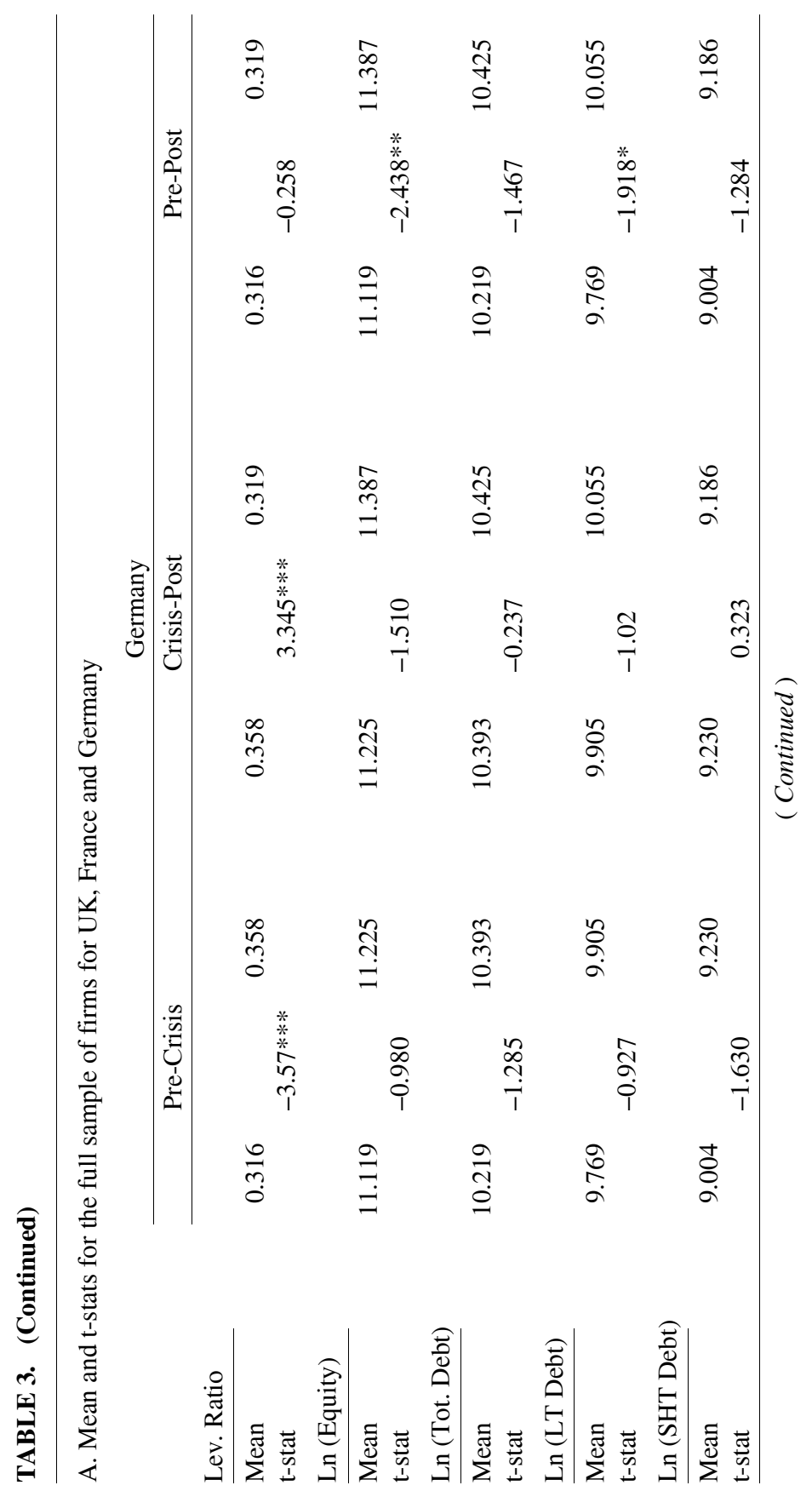




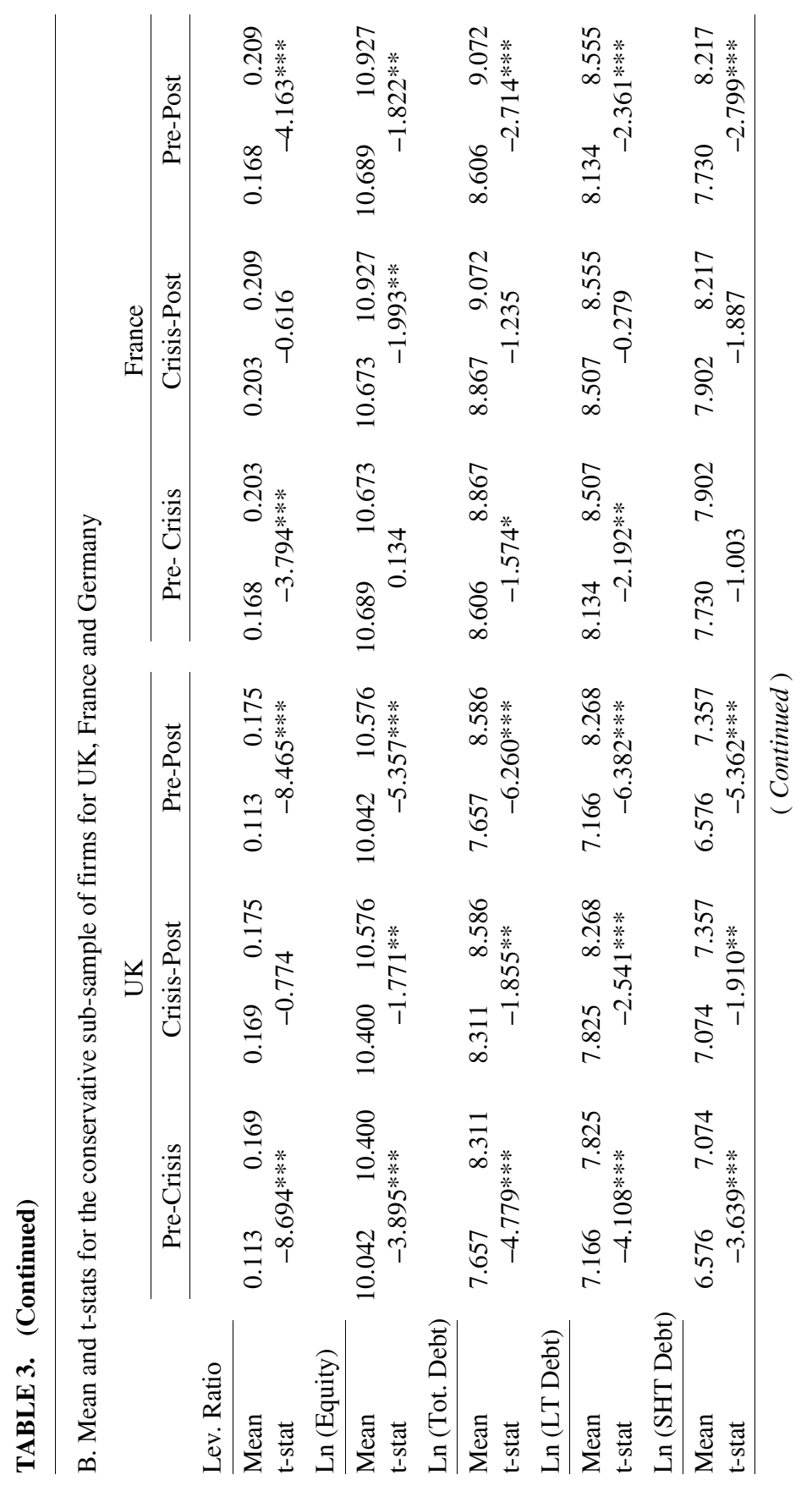




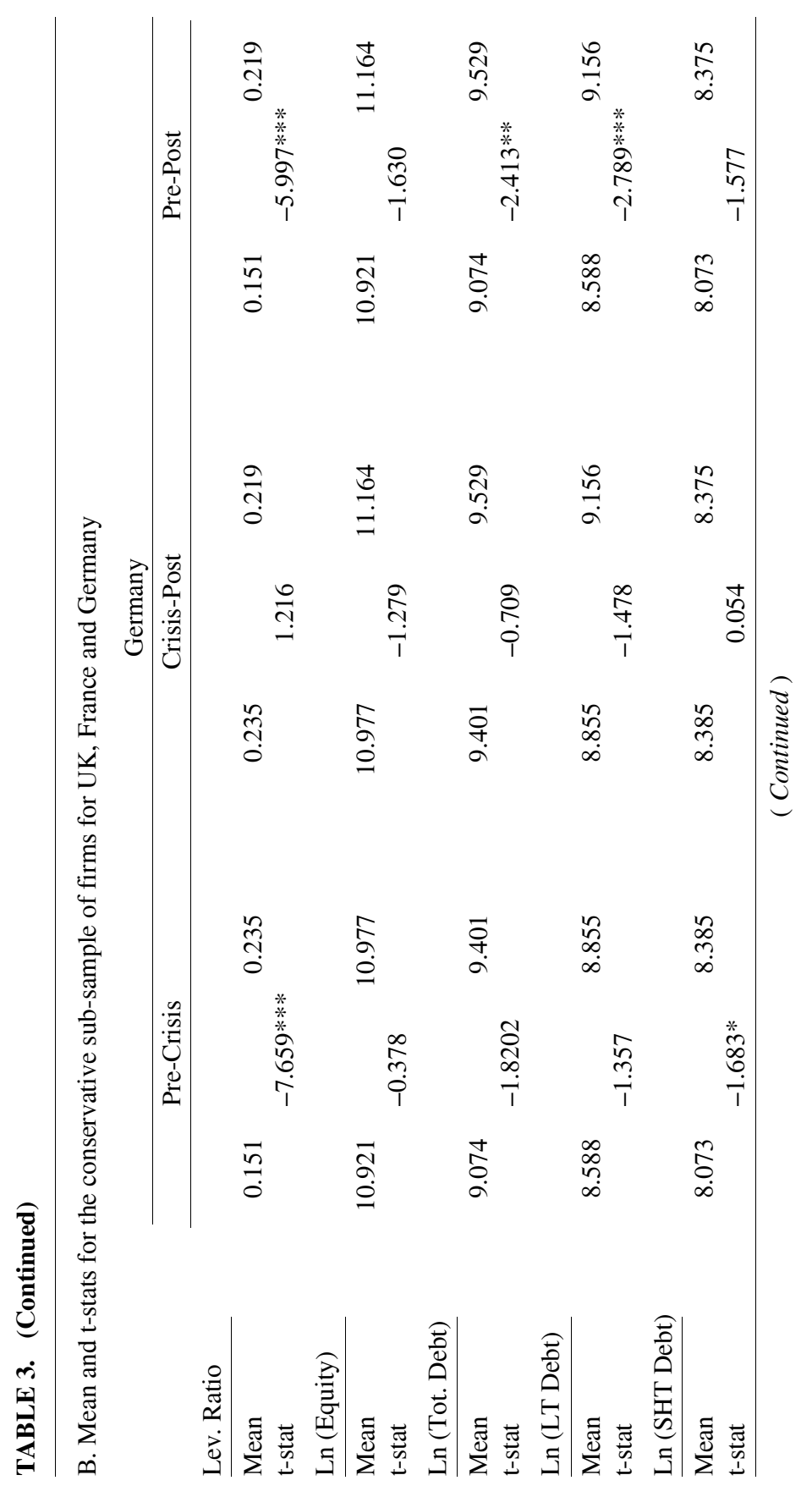




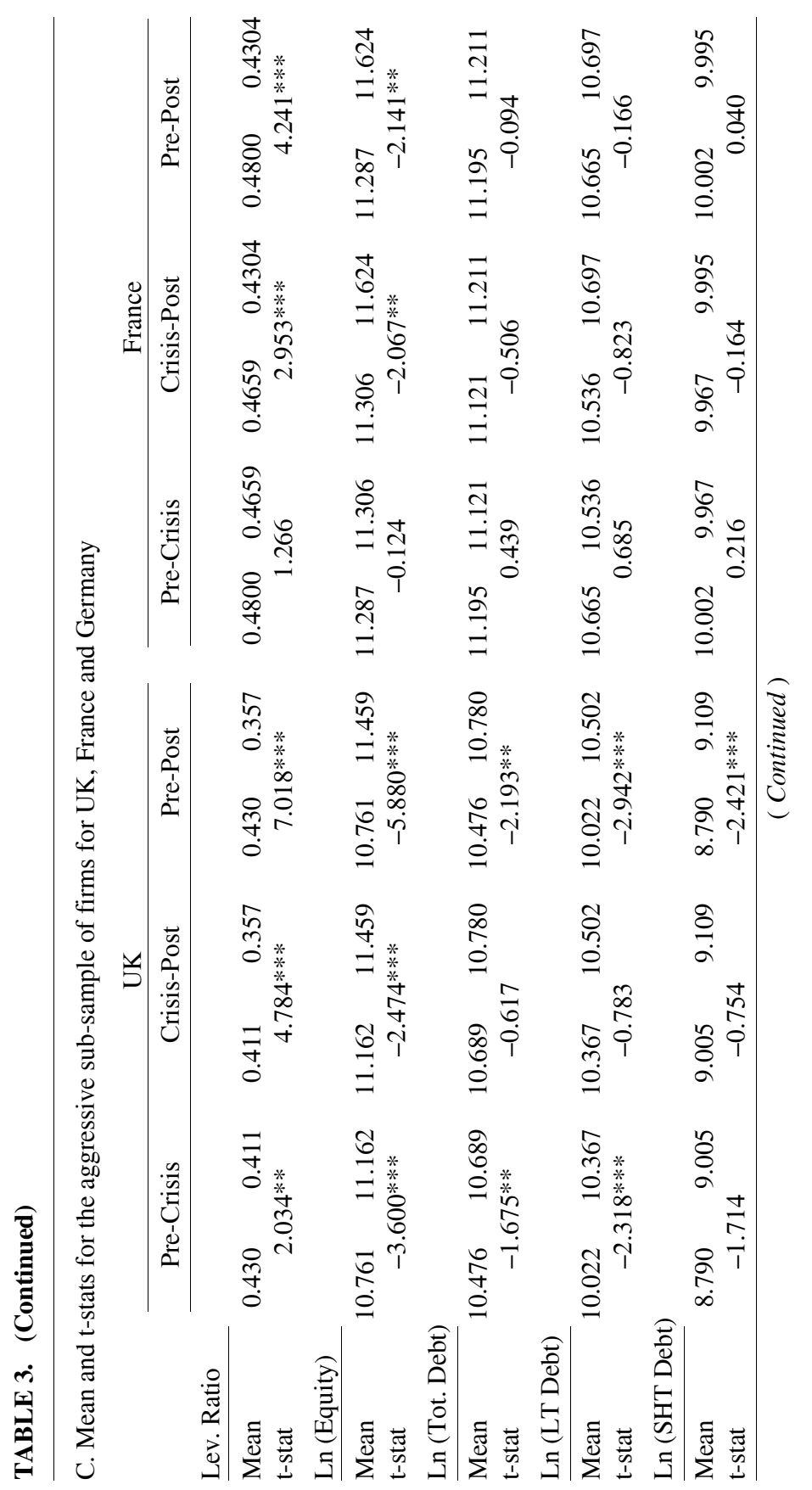




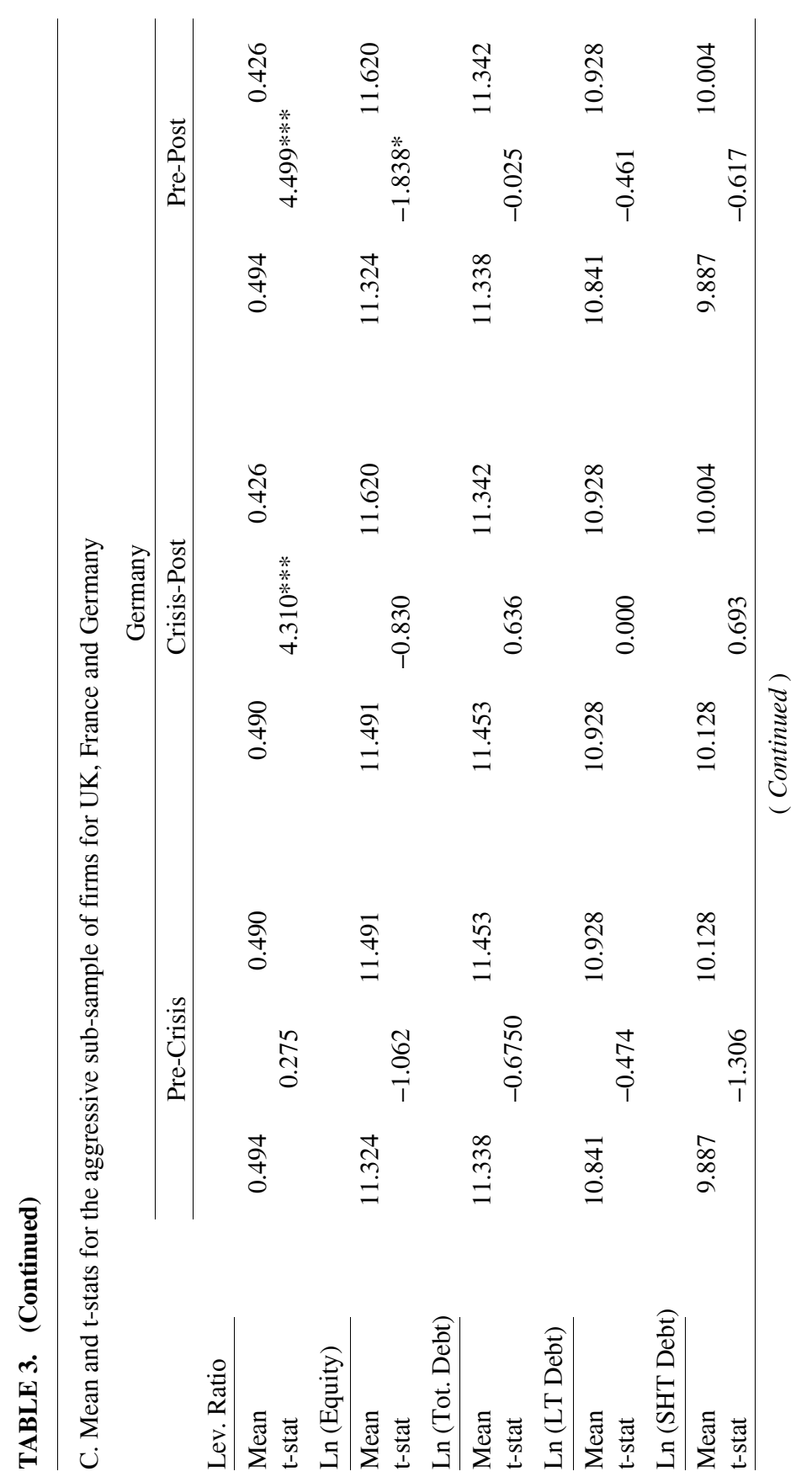




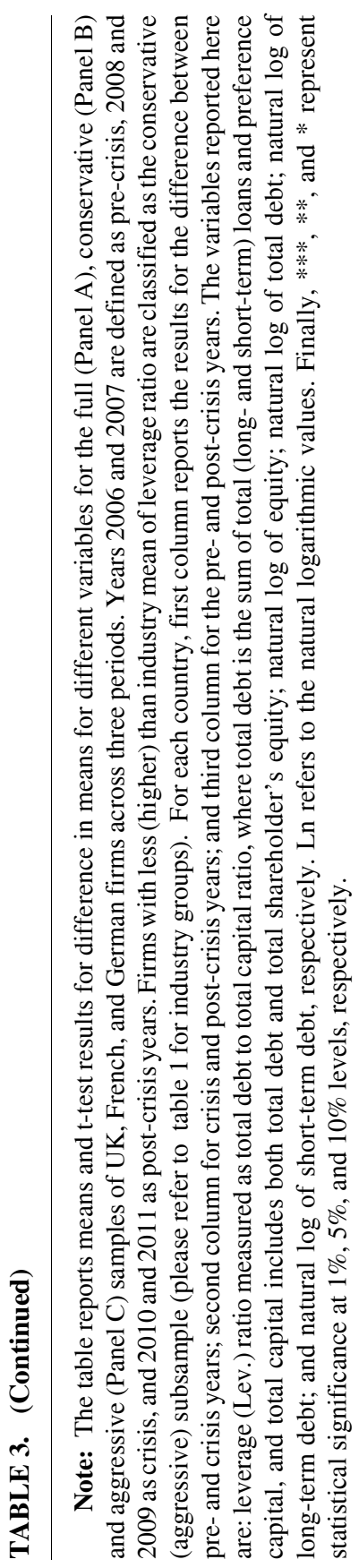


shows that changes in both short-term and long-term debts are significant for UK firms during the crisis and post-crisis years but insignificant for French and German firms. These results suggest that changes in both short- and long-term debts are mainly responsible forchanges in leverage ratios from pre- to crisis and post-crisis periods in the UK, however this is not the case for France and Germany. This seems plausible in a market-based economy (such as UK) as compared to a bank-based economy (such as France or Germany).

Panel B of table 3 shows that leverage ratios increase from pre- to crisis and pre- to post-crisis periods for the conservative subsamples across all three major European countries. For UK, this increase is due to increases in both equity and debt (short- and long-term) from pre- to crisis and to post-crisis periods. For French subsample, this increase is due to an increase in both short- and long-term debt and equity from pre- to post-crisis years, whereas for German subsample, it is due to changes in long-term debt from pre- to post-crisis periods.

Panel $\mathrm{C}$ of table 3 shows that leverage ratios decrease steadily for UK, French and German aggressive subsamples during both crisis and post-crisis periods. For UK subsample, a statistically significant decrease from pre- to crisis period is observable but this is not the case for French and German subsamples. However, the decrease becomes statistically significant from pre- to post-crisis periods for all three subsamples. This decrease is mainly due to an increase in equity, either in the crisis or post-crisis periods. For the UK, this study also finds a significant increase in debt during the crisis period but the increase in debt is smaller than the increase in equity.

Figure 2 plots the graphs of the yearly averages (2006-2011) of leverage ratios for conservative and aggressive subsamples in the three countries. It shows a steady increase in leverage ratios for conservative subsamples and a steady decrease for aggressive subsamples across the three countries from pre-crisis to post-crisis years. It is also interesting that the movement in leverage ratios for conservative firms in the preand crisis years and for aggressive firms in the post-crisis year are almost similar for firms in the UK (a market-based economy) and Germany (a bank-based economy). The results for the conservative and aggressive subsamples are in line with those reported by Leary and Roberts (2005). They find that leverage ratios are more likely to increase (decrease) if they are relatively low (high).

\section{B. Regression results}

Panel A of table 4 reports regression results for full samples in three countries (UK, France, and Germany). The main variables of interest are 
Conservative subsample:

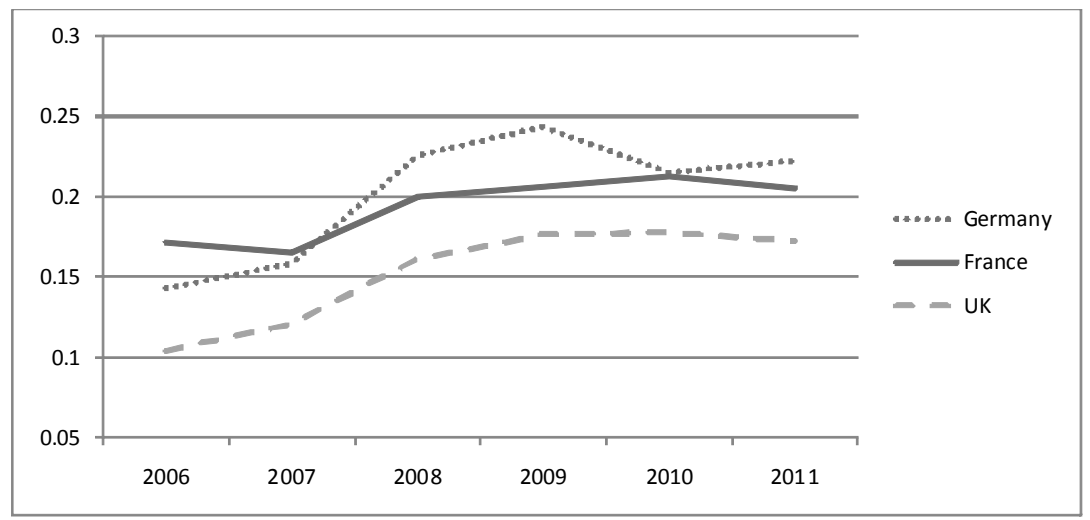

\section{Aggressive subsample:}

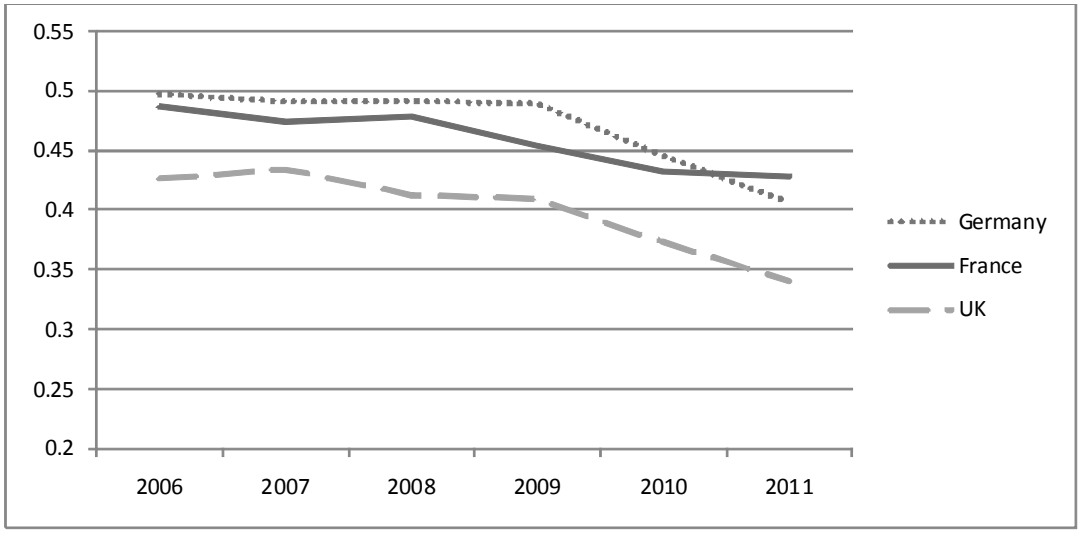

FIGURE 2.- Graphs of annual mean leverage ratios for conservative and aggressive subsamples for UK, France and Germany.

Note: The graphs show annual mean leverage ratios for UK, French and German firms for their conservative and aggressive subsamples, respectively. Firms with less than industry mean leverage ratio are identified as conservative and those with higher than industry mean value are named as aggressive subsamples (please refer to table 1 for industry groups). Leverage ratio is calculated as total debt to total capital ratio, where total debt is measured as the sum of total (long- and short-term debt) loans and preference capital, while total capital includes both total debt and total shareholder's equity of sample firms over the period 2006-2011. 
the crisis $(C D)$ and post-crisis dummies $(P O C D)$. Regression results (Equations 1 and 2) for full samples of UK and Germany show that the coefficients for $C D$ for these two countries are positive and statistically significant, but for French sample this coefficient is insignificant. These results suggest that leverage ratios are higher for UK and German firms during the crisis period (2008-2009) than during pre-crisis period even after controlling for time-varying effects of determinants of capital structure, as shown in Equation 2. While this evidence is similar to that of Fosberg (2012) for the US market, it is inconsistent with the results reported by Akbar, Rehman, and Ormrod (2013) for UK private firms. The coefficients for the post-crisis dummies across the three countries are statistically insignificant for the full sample based on both regression models. These findings support the univariate results reported earlier and are in line with Fosberg's (2012) which suggests that leverage ratios for the US firms in post-crisis periods revert back to their pre-crisis levels. Overall, these results are also consistent with those of Kayhan and Titman (2007) and Leary and Roberts (2005) that over time leverage ratios move towards target levels.

Regression results (Equations 1 and 2) in Panel B of table 4 for conservative subsamples show that coefficients for both the crisis $(C D)$ and post-crisis $(P O C D)$ dummy variables are positive and statistically significant for all three countries. The results highlight the fact that leverage ratios for conservative firms increase during the crisis and post-crisis periods across the three countries, despite controlling for time-varying changes in factors affecting capital structure.

Panel C of table 4 reports regression results (Equations 1 and 2) for aggressive subsamples. The results indicate negative and statistically significant coefficients for post-crisis dummy $(P O C D)$ variable across the three countries for these subsamples. These findings are opposite to those of conservative subsamples, as expected. Further, this study finds a marginally significant and negative coefficient for the crisis dummy $(C D)$ for French subsample indicating that leverage ratio changes for aggressive subsample occurred in the post-crisis period. Overall, these findings are consistent with the results reported in table 3 Panels B and $\mathrm{C}$ and suggest that the changes in the leverage ratios for conservative and aggressive subsamples are significant but in opposite directions.

The coefficients for the crisis dummy $(C D)$ in equation 1 for the full samples in UK and Germany indicate that the increase in leverage ratios (between 2 and 3 percentage points) though statistically significant is economically small. 


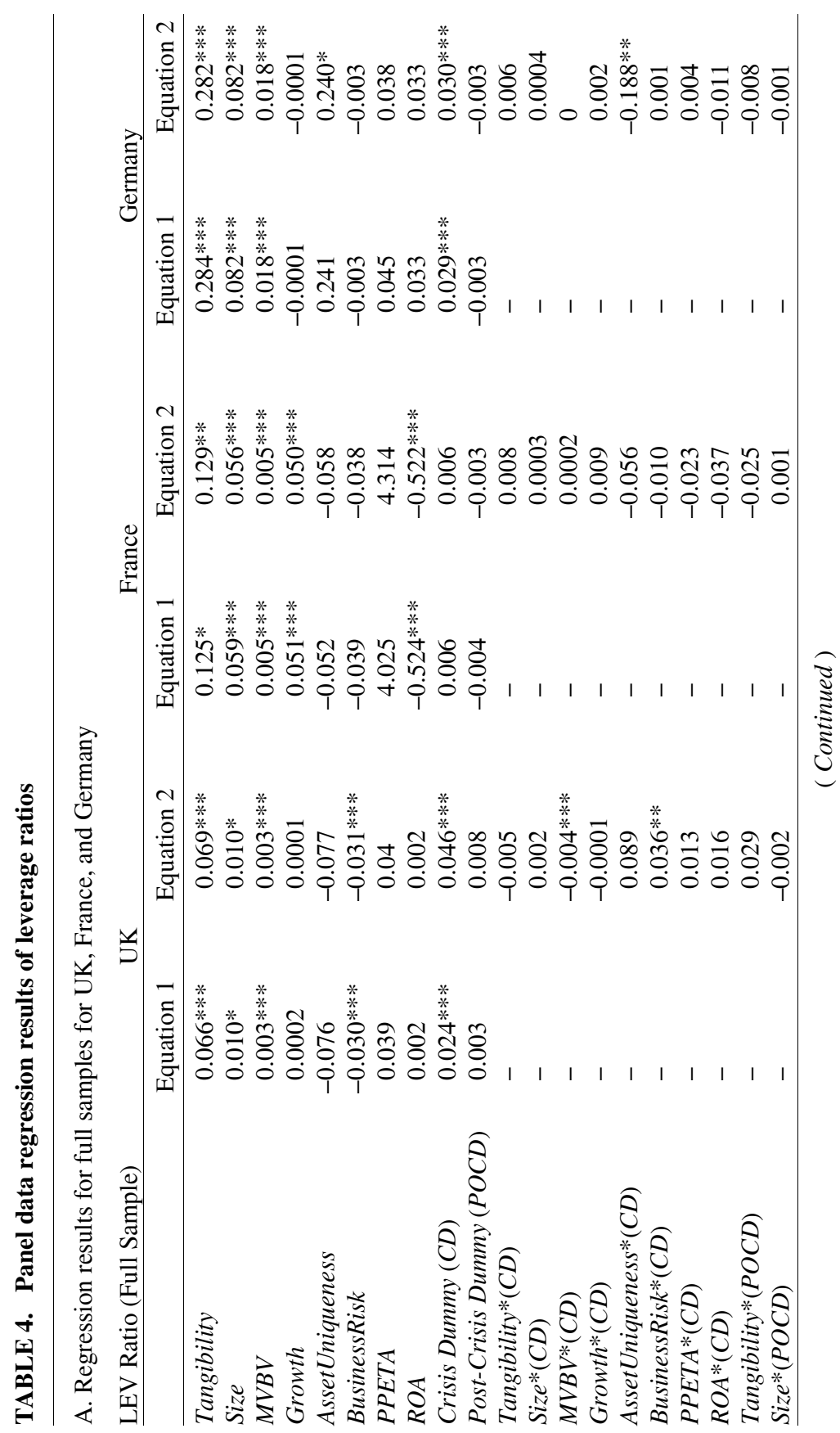




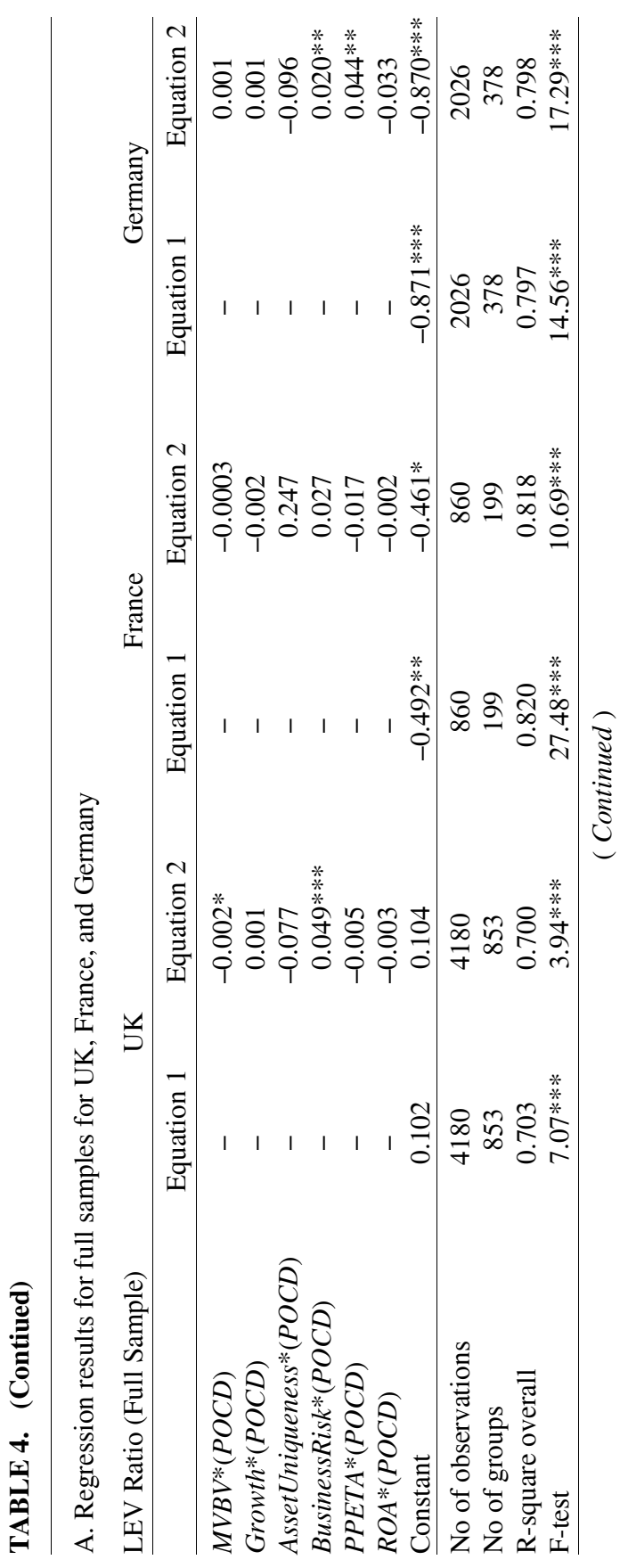




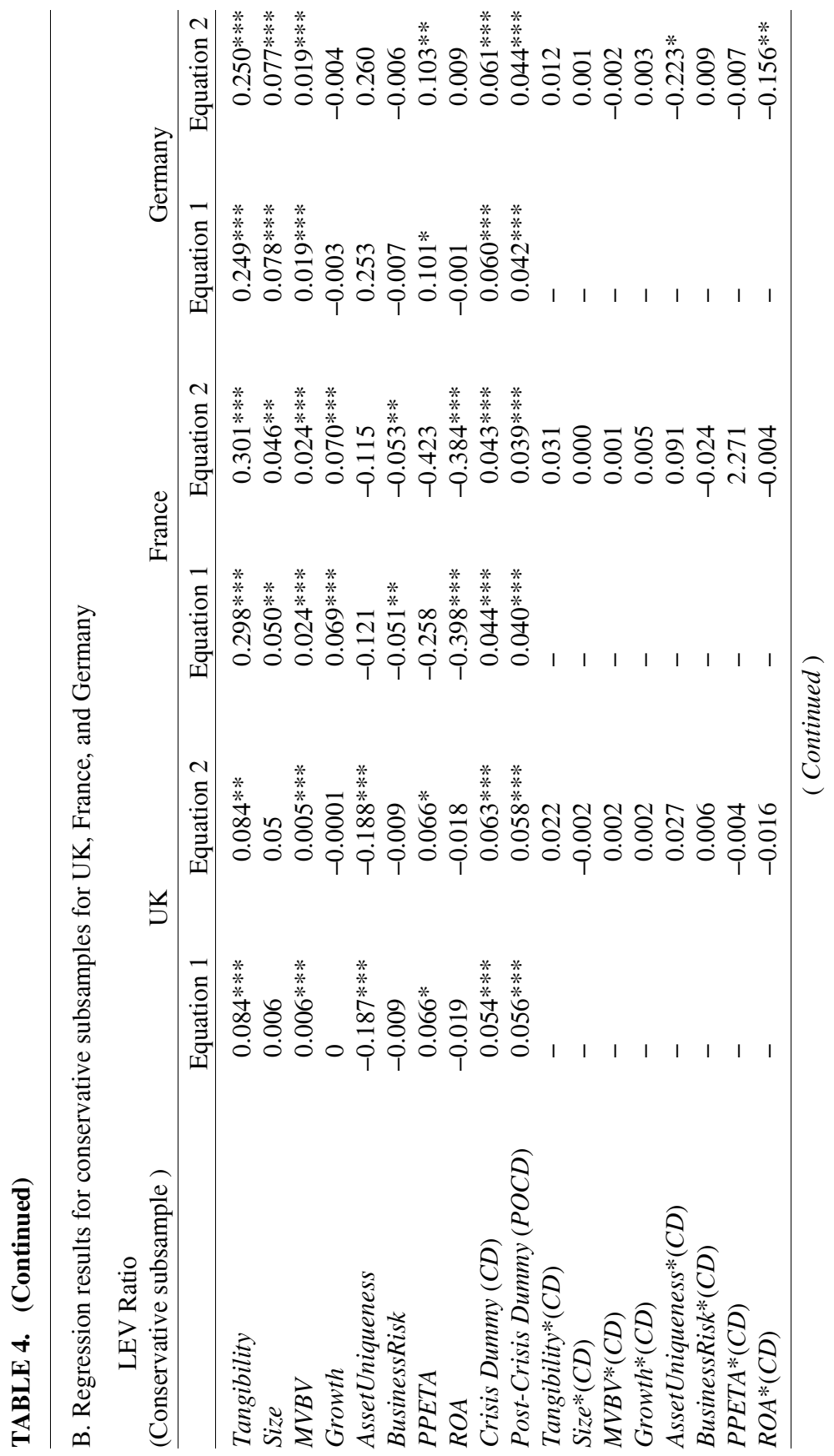




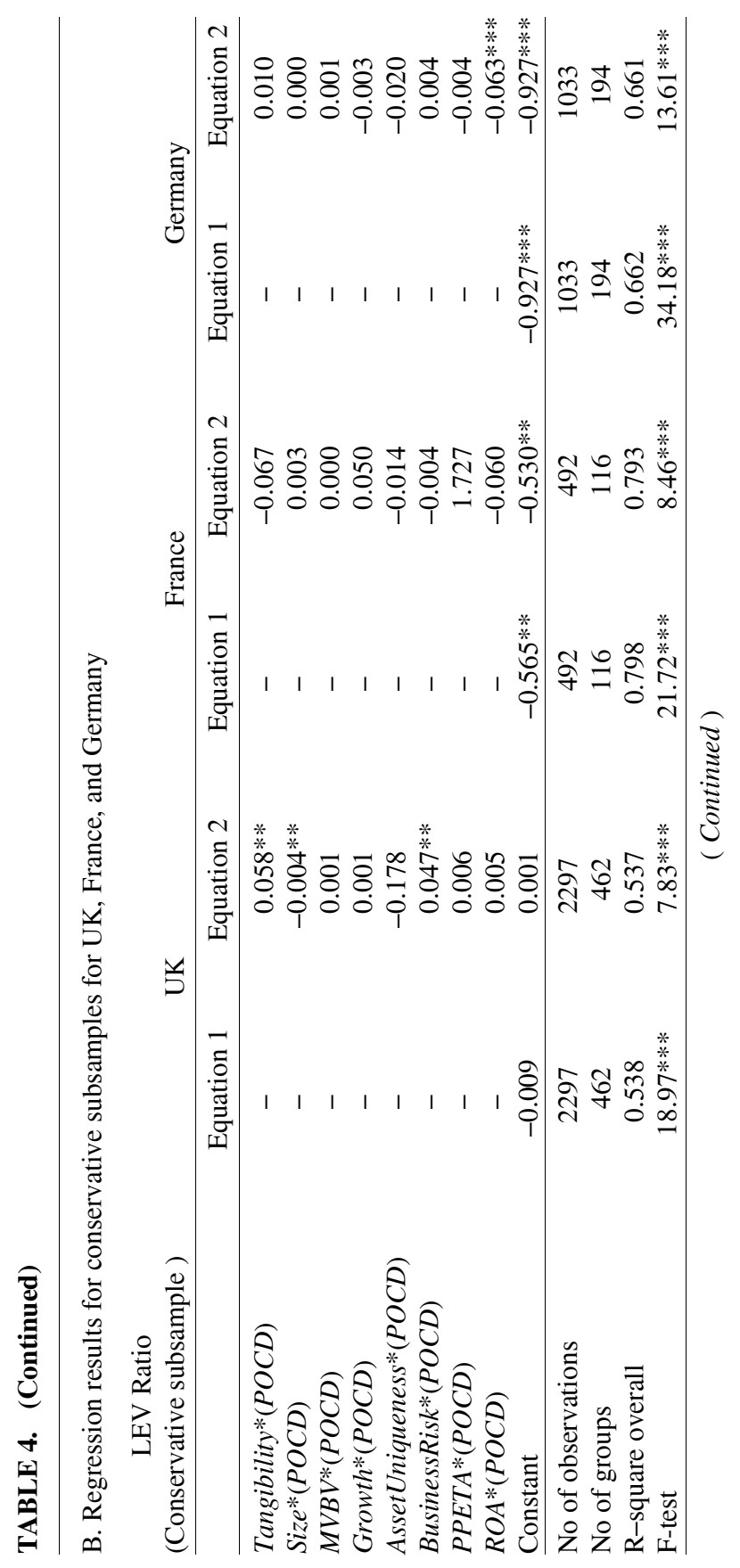




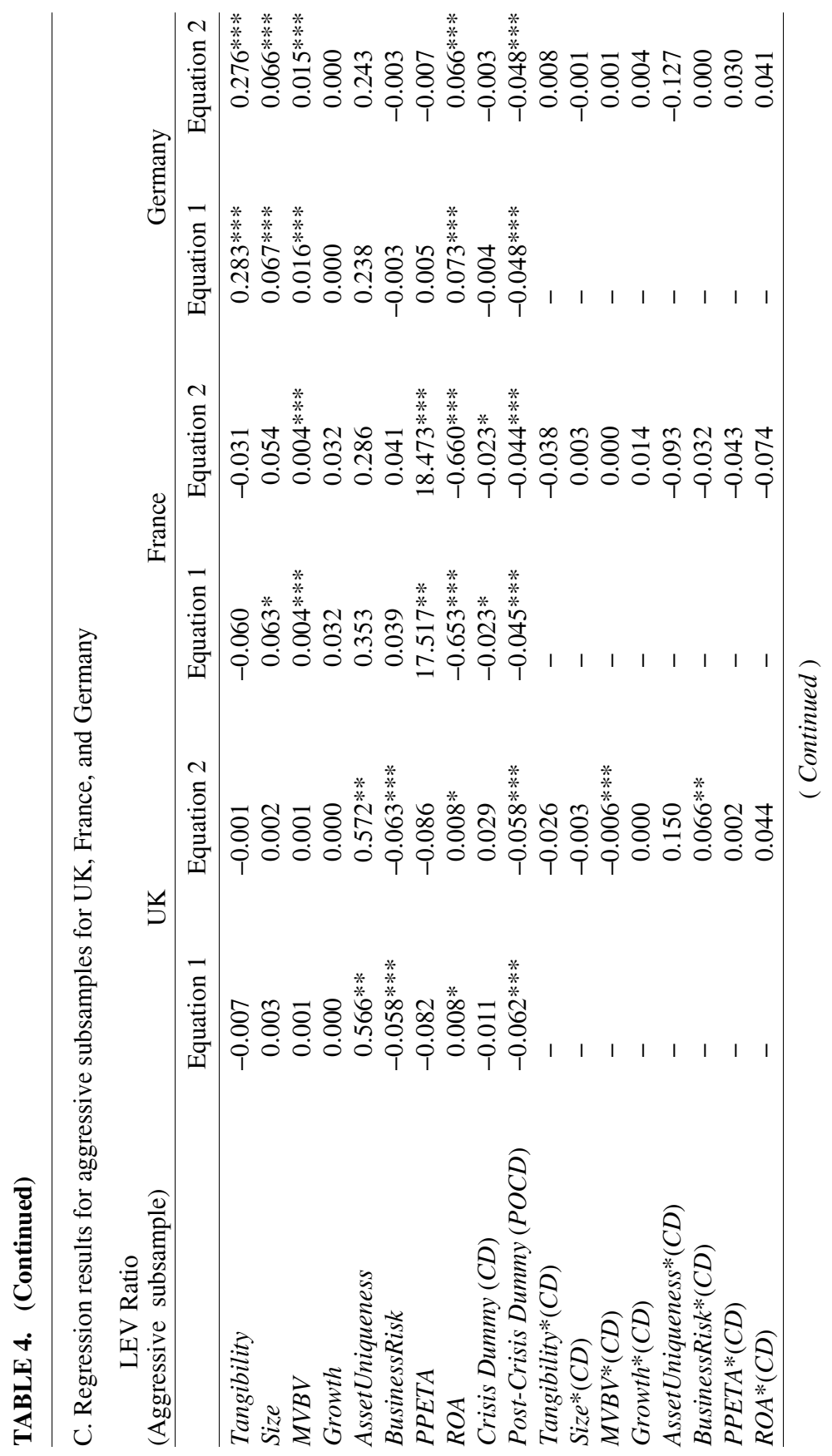




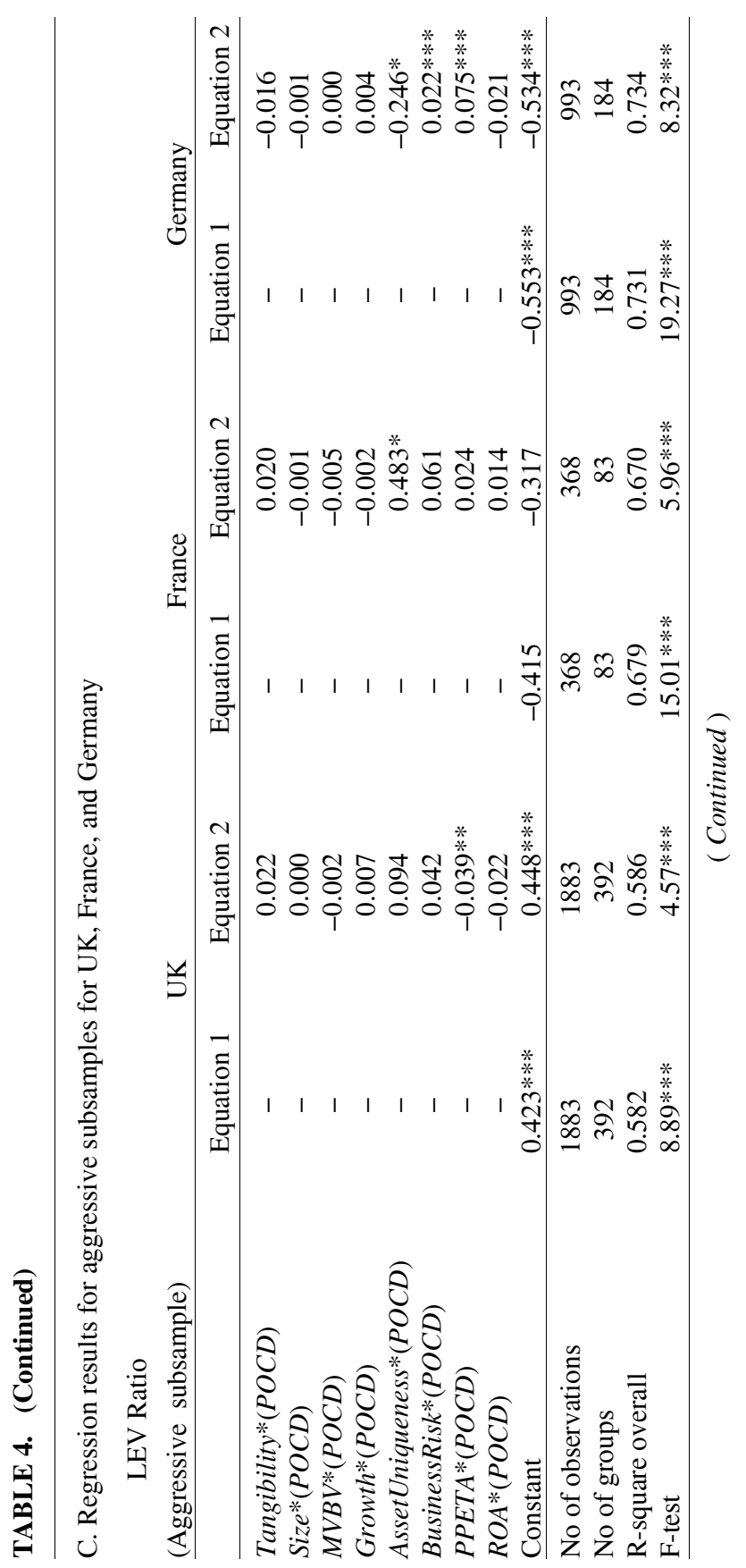




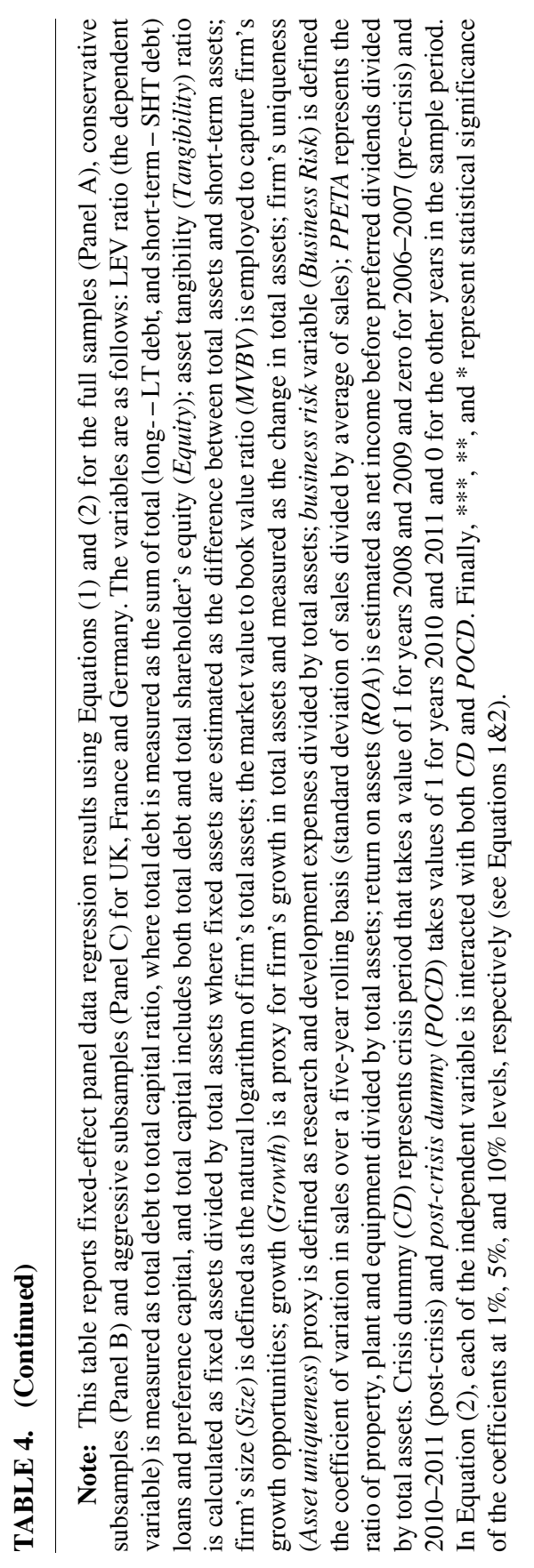


However, this paper finds that the corresponding increase for conservative subsamples during the crisis period is economically larger (between 4.4 and 6.0 percentage points) across the three countries. The economic impact of the crisis is also captured by the post-crisis dummy $(P O C D)$ coefficients across the three countries showing an increase of 4.0 and 5.6 percentage points for the conservative subsamples and a decrease of 4.5 and 6.2 percentage points for the aggressive subsamples, as compared to the pre-crisis period. Results from equation 2, across all subsamples, show that the significant impact of crisis and post-crisis dummies persists even when the interaction dummies with the control variables are included.

\section{Summary and Conclusion}

This study contributes to the extant literature by examining the capital structure or leverage ratios of non-financial/non-utility firms in three main European countries (UK, France and Germany) around 2007-08 financial crisis. The sample period is segregated into three periods of interest: 2006-2007 as the pre-crisis period, 2008-2009 as the crisis period, and 2010-2011 as the post-crisis period. Univariate and panel data regression results reveal that, on average, leverage ratios significantly increase from pre- to crisis periods and then revert to pre-crisis levels in the UK and Germany. These changes are insignificant across the three periods for French firms. This study finds that during the crisis period, the increase in leverage ratios for UK firms is mainly due to the use of both short- and long-term debt, whereas in the post-crisis period the reversion back to the pre-crisis levels is mainly due to the use of equity. There are no significant changes in either shortor long-term debt of full samples of French and German firms, either in the crisis or post-crisis years.

Considering the availability of excessive leverage for firms before the financial crisis (for example, Fosberg, 2012), the sample firms of each country are segregated into two subsamples (conservative and aggressive) based on the levels of their pre-crisis leverage ratios as compared to their industry average ratios during this period. Firms are considered to follow a conservative (aggressive) funding strategy in the pre-crisis period if they had lower (higher) than industry mean leverage ratio during that period. The evidence on conservative subsamples shows a significant increase in leverage ratios from pre- to crisis period. 
Furthermore, t-test results reveal that the increase in leverage ratios to crisis period for UK conservative firms is mainly due to the significant increase in debt rather than in equity. This study does not find such strong evidence on the use of debt or equity for French and German conservative firms.

Findings from the aggressive firms indicate that overall the leverage ratios in the post-crisis period are significantly lower than their pre-crisis levels across the three countries. While this decrease is more pronounced from the crisis to post-crisis period for French and German aggressive sub-samples, the leverage ratios for UK subsample have significantly and gradually fallen from pre- to crisis and then in post-crisis period. This gradual decline is mainly due to the significant reduction in equity levels across the three periods. Additionally, t-test results indicate a significant increase in debt (though lower than the increase in equity) for UK aggressive subsample from pre- to crisis period. Finally, this study does not find any significant evidence on increases in debt or equity levels for either French or German aggressive sub-samples.

Overall, the results show that 2007-08 financial crisis had a significant impact on leverage ratios of firms in both market-based (the UK) and bank-based (Germany and France) economies. Leverage ratios of sample firms in the post-crisis period revert back to their pre-crisis levels with adjustments during the crisis years. Consistent with Leary and Roberts (2005), this paper finds that firms with lower than industry-average debt ratios experience an increase in debt ratios and those with higher than industry-average debt ratios experience a decrease in these levels from pre- to the post-crisis periods.

Accepted by: Prof. P. Theodossiou, Editor-in-Chief, July 2014

\section{References}

Akbar, S.; Rehman, S.; and Ormrod, P. 2013. The impact of recent financial shocks on the financing and investment policies of UK private firms. International Review of Financial Analysis 26(4): 59-70.

Al-Najjar, B., and Hussainey, K. 2011. Revisiting the capital-structure puzzle: UK evidence. Journal of Risk Finance 12(4): 329-338.

Alter, A., and Schóler, Y.S. 2012. Credit spread interdependencies of European states and banks during the financial crisis. Journal of Banking \& Finance 36(12): 3444-3468. 
Balsari, C. K., and Kirkulak, B. 2010. Effect of financial crises on the capital structure choice: Evidence from Istanbul Stock Exchange (ISE). Working paper. Izmir: Dokuz Eylul University.

Bancel, F., and Mittoo, U. 2011. Financial flexibility and the impact of the global financial crisis: Evidence from France. International Journal of Managerial Finance 7(2): 179-216.

Booth, L.; Aivazian, V.; Demirguc-Kunt, A.; and Maksimovic, V. 2001. Capital structures in developing countries. The Journal of Finance 56: 87-130.

Brun, M.; Chai, F.; Elgg, D.; Esteban, A.; van Gastel, G.; Körting, T.; and Vivet, D. 2013. Profitability, equity capitalization and net worth at risk. Working Paper, European Committee of Central Balance Sheet Data Office. http://www.banque-france.fr/fileadmin/user_upload/banque_de_france/E conomie_et_Statistiques/WP_Study_Group_ECCBSO_2013_V1.0.pdf

Brunnermeier, M. K. 2008. Deciphering the liquidity and credit crunch 2007-08. NBER working paper no.14612. Cambridge, Mass: National Bureau of Economic Research.

Campello, M.; Graham, J. R.; and Harvey, C. R. 2010. The real effects of financial constraints: Evidence from a financial crisis. Journal of Financial Economics 97(3): 470-487.

Chen, J. J. 2004. Determinants of capital structure of Chinese-listed companies. Journal of Business Research 57(12): 1341-1351.

Dang, V. A. 2013. Testing capital structure theories using error correction models: evidence from the UK, France and Germany. Applied Economics 45(2): 171-190.

Demirgüç-Kunt, A., and Maksimovic, V. 1999. Institutions, financial markets and firm debt maturity. Journal of Financial Economics 54: 295-336.

Fosberg, R. H. 2012. Capital structure and financial crisis. Journal of Finance and Accountancy 11:46-52

Frank, M. Z., and Goyal, V. K. 2003. Testing the pecking order theory of capital structure. Journal of Financial Economics 67(2): 217-248.

Graham, J. R., and Harvey, C. R. 2001. The theory and practice of corporate finance: Evidence from the field. Journal of Financial Economics 60: 186-243.

Graham, J. R.; Leary, T. M.; and Roberts, M. R. 2014. A century of capital structure: The leveraging of corporate America. NBER working paper no. 19910. Cambridge, Mass: National Bureau of Economic Research.

Harris, M., and Raviv, A. 1991. The theory of capital structure. The Journal of Finance 46(1): 297-355.

Hodson, D., and Quaglia, L. 2009. European perspectives on the global financial crisis: Introduction. Journal of Common Market Studies 47(5): 939-953.

Huang, G., and Song, F. M., 2006, The determinants of capital structure: Evidence from China. China Economic Review, 17(1), 14-36. 
Kahle, K. M., and Stulz, R. M. 2013. Access to capital, investment, and the financial crisis. Journal of Financial Economics 110(2): 280-299.

Kayhan, A., and Titman, Sh. 2007. Firms' histories and their capital structures. Journal of Financial Economics 83: 1-32.

Leary, M. T., and Roberts, M. R. 2005. Do firms rebalance their capital structures? The Journal of Finance 60(6): 2575-2619.

Lemmon, M. L.; Roberts, M. R.; and Zender, J. F. 2008. Back to the beginning: persistence and the cross-section of corporate capital structure. The Journal of Finance 63(4): 1575-1608.

Lim, Y. 2003. Sources of corporate financing and economic crisis in Korea: A micro-evidence. NBER working paper no. 9575. Cambridge, Mass: National Bureau of Economic Research.

Pattani, A.; Vera, G.; and Wackett, J. 2011. Going public: UK companies' use of capital markets. Bank of England Quarterly Bulletin 51(4): 319-330.

Rajan, R., and Zingales, L. 1995. What do we know from capital structure? Some evidence from the international data. The Journal of Finance 50: 1421-1460.

Voutsinas K., and Werner R.A. 2011. Credit supply and corporate capital structure: Evidence from Japan. International Review of Financial Analysis 20(5): 320-334. 